\title{
Rethinking the Applicability of Emission Trading System in ASEAN: Lesson from the European Emission Trading System
}

\author{
Yovi Cajapa Endyka, Universitas Mulawarman, \\ Yulisa Wineyni, Universitas Mulawarman, \\ Mahfut, Universitas Mulawarman, \\ M. Muhdar,* Universitas Mulawarman, \\ Haris Retno Susmiati, Universitas Mulawarman,
}

\begin{abstract}
Abstrak
Perdagangan karbon adalah masalah universal yang dapat dipraktikkan di setiap negara, termasuk di kawasan seperti Uni Eropa. Uni Eropa adalah satu-satunya organisasi regional yang berpartisipasi sebagai pihak dalam United Nations Framework Convention on Climate Change (UNFCCC). Sejauh ini Uni Eropa telah membentuk kerangka hukum yang paling ambisius untuk pengurangan emisi karbon di dunia. ASEAN sebagai asosiasi perkumplan negara-negara di Asia Tenggara dengan tingkat emisi yang cukup tinggi, baik dari kegiatan berbasis industri maupun aktifitas di darat belum menunjukkan kerjasama jual beli karbon antar anggota ASEAN seperti yang telah dlakukan oleh Uni Eropa. Apakah ASEAN memiliki skema perdagan emisi tersendiri atau ada kema lain yang dapat dicontoh seperti yang terjadi di wilayah Uni Eropa.
\end{abstract}

Kata kunci: Perdagangan Karbon; Uni Eropa; ASEAN; Perubahan Iklim

\section{Introduction}

The implementation of ASEAN Economic Community (AEC) was implemented in the end of 2015. The AEC is one of the pillars of the ASEAN Community were set out in the Bali Concord II. ASEAN hopes to establish a single market and production in the end of 2015.1 The ASEAN Economic Community shall be the goal of regional economic integration by 2015. AEC envisages the following key characteristics: (a) a single market and production base, (b) a highly competitive economic region, (c) a region of equitable economic development, and (d) a region fully integrated into the global economy. ${ }^{2}$

The first AEC characteristic seeks to create a single market and production base through free flow of goods, services, investment, skilled labor and freer flow of capital. The second characteristic

\footnotetext{
${ }^{1}$ Ana Syukriah, "Peningkatan Eksistensi UMKM Melalui Comparative Advantage dalam Rangka Menghadapi MEA 2015 di Temanggung", Economics Development Analysis Journal, Vol.2 No.2 2013, p. 111.

2 ASEAN, ASEAN Economic Community, http://www.asean.org/communities/asean-economic-community Jakarta, accessed on Sunday, March 29, 2020, at 1.30 p.m.
} 


\section{Borneo Law Review Vol.4 No.2 \\ Desember 2020}

helps to create a business-friendly and innovation-supporting regional environment through the adoption of common frameworks, standards and mutual co-operation across many areas, such as in agriculture and financial services, and in competition policy, intellectual property rights, and consumer protection. It also supports improvements in transport connectivity and other infrastructure networks. ${ }^{3}$ The third characteristic seeks to achieve equitable economic development through creative initiatives that encourage small and medium enterprises to participate in regional and global value chains and focused efforts to build the capacity of newer ASEAN Member States to ensure their effective integration into the economic community. The fourth characteristic envisages ASEAN's full integration into the global economy pursued through a coherent approach towards external economic relations, and with enhanced participation in global supply networks. ${ }^{4}$

When the state member opened a single market in their own country, automatically the industry installation will growth in any state member. Climate change, induced by many different kinds of human activities, 5 it could be more largely factory which produce greenhouse gases in the region and will contribute to global warming, yet it is unfair when one state member produce massive carbon emission in otherwise other state member make an effort to reduce greenhouse gas. Justice concerns play a role in every kind of international negotiation at all levels, ${ }^{6}$ it is widely believed that emission trading programs have played a prominent role in environmental policy, especially for the purpose of reducing carbon emissions.

More importantly, the unit cost of emissions reductions depends strongly on policy design (for example, international trade in emissions reductions can help to equalize the unit cost across countries)..$^{7}$ As a result, a multiplicity of regional and national carbon trading markets emerged, including the Regional Emissions Trading Scheme in Australia, the Republic of Korea, and the USA which have a different targets relative to Business-As-Usual Emissions at 2020 to reduce Greenhouse Gas (GHG) such as European Union -13\%, Australia -20\%, USA 27\% and Republic of Korea more challenging that is $-30 \%$ GHG reduction. ${ }^{8}$ Notwithstanding, the most notably the

3 ASEAN, AEC, http://www.asean.org/storage/2012/05/56.-December-2015-Fact-Sheet-on-ASEANEconomic-Community-AEC.pdf Jakarta, downloaded on Sunday, March 29, 2020, at 3.30 p.m.

${ }^{4}$ Ibid.

${ }^{5}$ Mizan R. Khan, 2014, Toward a Binding Climate Change Adaptation Regime, Routledge, New York, p. 3.

${ }^{6}$ Marco Grasso, 2010, Justice in Funding Adaptation under the International Climate Change Regime, Springer, New York, p. 2.

${ }^{7}$ Australian Government, 2015, Comparing Countries' Emissions Targets a Practical Guide, Commonwealth of Australia (Climate Change Authority), Australia, p. 15.

${ }^{8}$ See, emissions reduction compared to business-as-usual (bau) Change relative to BAU can provide a better indicator of effort than absolute changes, because it focuses on what emissions would have been without further 


\section{Borneo Law Review Vol.4 No.2 Desember 2020}

Emissions Trading System set up by the European Union (EU). The European Union Emissions Trading System (EU ETS) is the major emission cap-and-trade trading program across the world, accounting for about $\$ 175$ billion a year. The history of the EU ETS can be traced back to 2005, and today it allocates tradable emissions permits to more than 12 large power stations and industrial plants in more than 20 countries, accounting for about half of the EU's total greenhouse gas emissions in aggregate. ${ }^{9}$

Scientific evidence shows that anthropogenic GHG emissions have an impact on climate change, ${ }^{10}$ as national and international policies are developed to mitigate climate change, concern is growing about the compatibility of climate change regimes with international trade rules. ${ }^{11}$ The European Union is the only regional organization participating as a party to the United Nations Framework Convention on Climate Change (UNFCCC). It has established the most ambitious legal framework for absolute emission reductions in the world so far. ${ }^{12}$ Is should ASEAN follow the EU emission trading system to reducing greenhouse gases in the region.

This study will assess how the EU ETS play the role in the region compare to ASEAN'S commitment on climate change. This study will focus on Rethinking the Applicability of Emission Trading System in ASEAN: Lesson from the European Emission Trading System.

\section{European Union Emissions Trading System's Model}

The EU Emissions Trading System (EU ETS) is Europe's flagship tool to meet its carbon mitigation objectives. It remains the largest example of emissions trading in operation today, encompassing over 11,500 installations across 30 countries and covering approximately 40\% of total EU emissions. Its environmental impact can be assessed against two specific primary objectives to reduce GHG emissions efficiently, at a negotiated balance of cost and environmental

policy intervention. However, it can be challenging to project a consistent set of BAU emissions for different countries, which limits this metric's value for comparisons. BAU projections rely on modelling or other calculations, which are underpinned by many assumptions about the future state of economic activity, technology development and deployment, policy costs and so on. (Commonwealth Of Australia Climate Change Authority 2015:15)

${ }^{9}$ Yukun Shi, Sudharshan Reddy Paramati, and Xiaohang Ren, 2019, "The Growth of Carbon Markets in Asia: The Potential Challenges for Future Development", ADB Institute No. 987, p. 1

10 Ottavio Quirico, 2016, Climate Change and Human Rights An International and Comparative Law Perspective, Springer, New York, p. 1.

11 Gabrielle Marceau, 2016, Legal Issues on Climate Change and International Trade Law, Springer Nature, Switzerland, p. 3 .

12 Marjan Peeters, "An EU Law Perspective on the Paris Agreement: Will the EU Consider Strengthening its Mitigation Effort?" Koninklijke Brill NV Leiden, Climate Law 6 (2016) 182-195, p. 183. 


\section{Borneo Law Review Vol.4 No.2 \\ Desember 2020}

gain; and to promote corporate investment in low carbon technologies (both energy efficiency and low carbon energy sources). ${ }^{13}$ In its fundamental design, the EU ETS achieves a main environmental objective of capping power and industrial greenhouse gas emissions. However, understanding its wider impact is crucial. The EU ETS has the objective of "promoting reductions of greenhouse gas emissions in a cost-effective and economically efficient manner. ${ }^{14}$

The EU Emissions Trading System (EU ETS) is a 'cap and trade' system. It caps the total volume of GHG emissions from installations and aircraft operators responsible for around 50\% of EU GHG emissions. ${ }^{15}$ The system allows trading of emission allowances so that the total emissions of the installations and aircraft operators stays within the cap and the least-cost measures can be taken up to reduce emissions. The EU ETS is a major tool of the European Union in its efforts to meet emissions reductions targets now and into the future.

The trading approach helps to combat climate change in a cost-effective and economically efficient manner. Nevertheless, as the first and largest emissions trading system for reducing GHG emissions, the EU ETS covers more than 11,000 power stations and industrial plants in 31 countries, and flights between airports of participating countries. ${ }^{16}$ The system was first introduced in 2005, and has undergone several changes since then. The implementation of the system has been divided up into distinct trading periods over time, known as phases. The current phase of the EU ETS began in 2013 and will last until 2020.

The EU ETS is an important building block of the EU's environmental legislation. The Single European Act (SEA) of 1986, which revised the Treaty of Rome (1957), forms the legal basis for the EU ETS. The SEA added new momentum to European integration and to the completion of the internal market and expanded the powers of the Community, including on environmental issues, stating that the EU is permitted to put legislation in place to preserve, protect and improve the quality of the environment, to contribute towards protecting human health, and to ensure a prudent and rational utilization of natural resources.

\footnotetext{
13 Tim Laing, Misato Sato, et.al, 2013, “Assessing the effectiveness of the EU Emissions Trading Scheme”, Centre for Climate Change Economics and Policy, London, p. 1.

14 Joshua Prentice,2018, “The Revision of the European Union's Emissions Trading System Ahead of the Fourth Trading Period, 2021-2030" Koninklijke Brill NV Leiden, Climate Law 8 (2018) 338-348, p.339

15 European Union, 2015, EU ETS Handbook, European Commission, p. 4.

16 Ibid. p. 9.
} 


\section{Borneo Law Review Vol.4 No.2 \\ Desember 2020}

The EU ETS is an environmental law, ${ }^{17}$ and therefore falls within European powers and so decisions about the EU ETS are made at the European level rather than the Member State (MS) (country) level. The key institutions involved are the European Parliament (the elected representatives of European citizens), the European Commission (Europe's civil service), and the European Council (representatives of MS governments in European decision-making). The European Commission (referred to as the Commission) is the only institution with the power to initiate a legislative proposal such as new regulations in the EU ETS or amendments to the EU ETS Directive. The European Council and Parliament can suggest amendments to the legislative proposal, which the Commission can include in an updated legislative proposal.18 In the end the Council and Parliament both need to approve the proposed legislation before it is adopted. Any new legislative proposals and most amendments to the EU ETS need to follow this co-decision procedure.

The EU ETS is a 'cap and trade' system, which works by capping overall GHG emissions of all participants in the system. The EU ETS legislation creates allowances which are essentially rights to emit GHG emissions equivalent to the global warming potential of 1 tone of $\mathrm{CO}_{2}$ equivalent ( $\mathrm{tCO} e$ ). The level of the cap determines the number of allowances available in the whole system. The cap is designed to decrease annually from 2013, reducing the number of allowances available to businesses covered by the EU ETS by $1.74 \%$ per year. This allows companies to slowly adjust to meeting the increasingly ambitious overall target for emissions reductions. ${ }^{19}$ The recent surge in allowance prices has been largely attributed to market actors anticipating the introduction of the Market Stability Reserve (MSR), one of several reforms aimed at boosting confidence in the EU ETS. Instead of constraining prices directly, the MSR adjusts the issuance of new allowances in response to the volume of unused allowances in circulation (the allowance bank). ${ }^{20}$

Each year, a proportion of the allowances are given to certain participants for free (for example in sectors where there is considered to be a potential risk, if they pay the full cost of all the pollution allowances they need, that production (and pollution) could shift to countries with less ambitious emissions reduction action - see Addressing the risk of carbon leakage), while the rest are sold, mostly through auctions. At the end of a year the participants must return an allowance

\footnotetext{
${ }^{17}$ See, EU Emissions Trading System (EU ETS) at https://ec.europa.eu/clima/policies/ets en

${ }^{18}$ European Union, Loc. Cit. p. 9.

${ }^{19}$ Ibid. p. 16

20 Dallas Burtraw and Michael Themann, 2018, Pricing Carbon Effectively: Lessons from the European Emissions Trading System, Resources for the fuure, Berlin, p. 11.
} 


\section{Borneo Law Review Vol.4 No.2 \\ Desember 2020}

for every tone of CO2e they emit during that year. If a participant has insufficient allowances then it must either take measures to reduce its emissions or buy more allowances on the market. Participants can acquire allowances at auction, or from each other.21

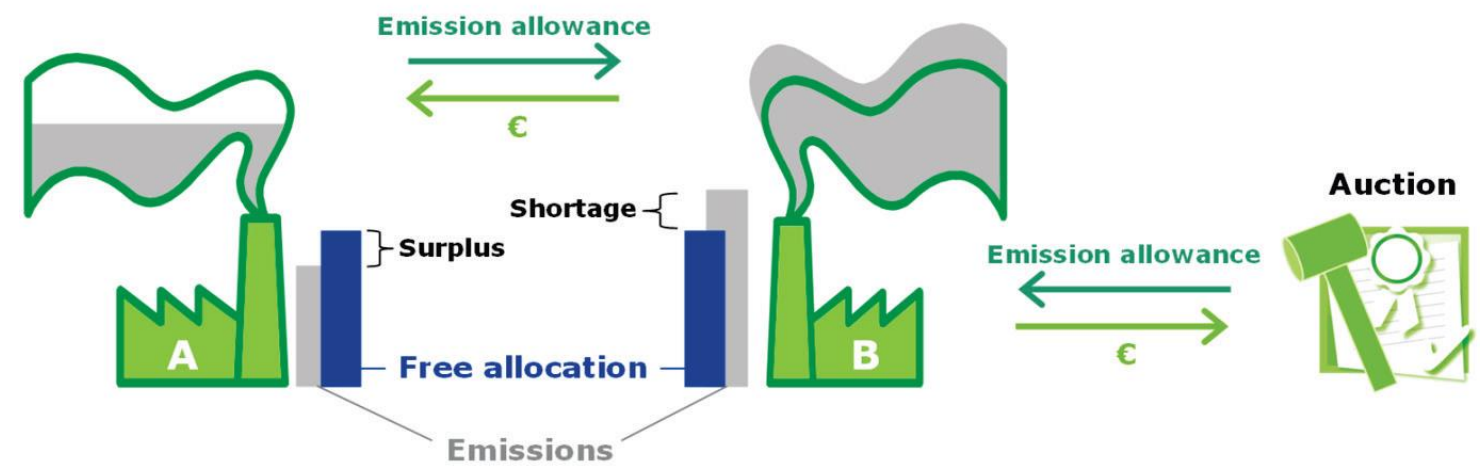

In this example, Factory $B$ does not have enough free allowances to cover its emissions, so it can either comply with the cap by buying allowances from factory $A$ or from the auction. If a participant's emissions of GHGs exceed the free allowances they were given at the start of the year, they can buy allowances from auctions or from other participants who have reduced their emissions and hold surplus allowances. Participants can also decide to bank allowances for use in later years. ${ }^{22}$ Allowances have value because there is a limited or capped supply and there is demand for them from those participants for whom the cost of making reductions are higher than for other participants. As such, it allows the effort to be redistributed between participants so that emissions reductions take place in areas where it costs less. This is good for business and the economy.

Compliance is ensured through the penalty and enforcement structure. Significant fines are imposed if companies fail to comply by surrendering sufficient allowances in time, set at €100/tCO2 and rising with EU inflation from 2013 (Penalties for non-compliance).23 In addition, firms face an obligation to surrender the allowances owed. Thus, the cap (i.e. the environmental target) is maintained effectively. Member States are responsible for laying down the rules to ensure installations comply with the EU ETS. ${ }^{24}$ The EU ETS Directive requires Member States to adopt "effective, proportionate and dissuasive" rules on penalties for breaches of the EU ETS Directive's requirements as stipulated in Article 16 (1). This wording allows the Member States to choose between criminal or administrative penalties and provides flexibility to implement a system of

${ }^{21}$ European Union, Op. Cit. p. 17

22 European Union, Lock. Cit. p. 16

${ }^{23}$ Ibid. p. 16-17

${ }^{24}$ Ibid. p. 134 


\section{Borneo Law Review Vol.4 No.2 Desember 2020}

penalties that best fits with their national legal systems whilst respecting the obligation to treat breaches of EU law in a manner that is similar to a breach of a wholly national rule or law.

The EU ETS Directive25 also provides specific rules in case of failing to surrender sufficient emission allowances. If an entity covered by EU ETS misses the system's annual deadlines for surrendering GHG emissions allowances, it runs the risk of triggering enforcement procedures. In phase 3 of the EU ETS, participants who fail to comply with their obligation to surrender allowances under the EU ETS are fined €100 per tCO2, adjusted with the EU inflation rate from 2013 onwards, for which they fail to submit an allowance. This fine is imposed by the relevant Member State authority. Furthermore, the shortfall in compliance is then added to the compliance target of the following year. In other words, any failure to comply is not written off, but must be addressed in addition to the next year's obligation.

Nevertheless, there is also "name-and-shame" sanction, ${ }^{26}$ but except for these two provisions, the ETS Directive leaves to the Member States discretion with respect to the detailed design of the rules on enforcement measures. Within the EU ETS, Member States are primarily responsible for monitoring and enforcing the behavior of the covered industries, and the European Commission may start infringement procedures if Member States fall short regarding this. ${ }^{27}$ Part of the problem is that the Commission may not always have sufficient information on possible lacks in implementation and/or execution by a Member State. The Assembly recognized that market based measures, are policy tools that are designed to achieve environmental goals. ${ }^{28}$

\section{ASEAN's Commitment on Climate Changes}

Climate change is a crucial issue and has become more pressing than ever in the region of Southeast Asia. Some of the member states of ASEAN are prone to climate impacts such as sea-level rise and extreme weather events like extreme drought and flood, ${ }^{29}$ Haze, and Food Security. ${ }^{30}$

\footnotetext{
${ }^{25}$ See. EU ETS Directive 2003/87/EC of The European Parliament and of The Council Regulations on penalties for non-compliance

${ }^{26}$ The consolidated EU ETS Directive 2003/87/EC of The European Parliament and of The Council, Regulations on penalties for non-compliance (Article 16).

${ }^{27}$ Marjan Peeters and Huizhen Chen, 2015, "Enforcement of emissions trading - sanction regimes of greenhouse gas emissions trading in the EU and China", Research Handbook on Emission Trading, p,115.

${ }^{28}$ Ruwantissa Abeyratne, 2014, Aviation and Climate Change In Search of a Global Market Based Measure, SpringerBriefs in Law, London, p. 62.

29 ASEAN Centre for Energy, https://accept.aseanenergy.org/wp-content/uploads/2019/12/EnergyInsight Multiole-Game.pdf Jakarta, downloaded on Sunday, May 31, 2020, at 4.05 p.m

30 Dewi Agha Putri, ASEAN-U.S Cooperation on Renewable Energy: ASEAN's Response to Climate Change Phenomenon, Intermestic: Journal of International Studies, Vol 3, No. 1, 2018, p. 34.
} 


\section{Borneo Law Review Vol.4 No.2 \\ Desember 2020}

Recognizing that Southeast Asia is the one of the most vulnerable regions of the world in terms of adverse climate change impacts that can undermine food and nutrition security and the attainment of SDGs, and capitalizing on its potential to strengthen the resilience of its people and ecosystems towards a more sustainable future, the development of a more comprehensive multi-sectoral strategic framework that builds on the existing ASEAN Multi-sectoral Framework on Climate Change: Agriculture and Forestry Towards Food Security (AFCC) was deemed of central importance. ${ }^{31}$

On 34th ASEAN Summit on 2019 in Thailand, ASEAN leader determined to strengthen efforts to mitigate the impact of climate change, including building climate-resilient communities, as well as address natural disasters in "timely and systematic manner. ${ }^{32}$ They have committed to facilitate the sharing of information and best practices to enhance the implementation of the Paris Agreement and Nationally Determined Contributions (NDCs) in order to build climate resilient communities in Southeast Asia.

Southeast Asia was the only region in the world where the share of coal, which is the single biggest source of greenhouse gas emissions globally, to generate power actually increased. At the same time, the continent will be hit particularly hard by climate change, making it imperative for the ASEAN region to step up climate action. ${ }^{33}$ The ASEAN Member States (AMS) have been working on harmonizing their environmental policies since the 1990s when the first regional Strategic Plan of Action on the Environment was introduced for the period 1999-2004. Joint climate co-operation activities were launched in the second of half of the 2000s. From one side, they aim to establish a joint representation at the global UNFCCC negotiations. From the other side, they work for the harmonization of climate change activities at the regional (ASEAN) level. ${ }^{34}$ AMS's commitment in responding to climate change is committed in the Road Map for the ASEAN Community 2009-2015.

Hence, to further mitigate such impacts ASEAN join the global pact and agree with The Paris Agreement, the Paris Agreement sets out a global framework to avoid dangerous climate change by

\footnotetext{
${ }^{31}$ AMAF Meeting, 2018, ASEAN Multi-Sectoral Framework for Climate Change: Agriculture and Forestry Towards Food and Nutrition Security and Achievement of SDGs (Proposed Integrated Framework for AFCC Component 4) Hanoi, p. 2.

32 Manila Bulletin, https://news.mb.com.ph/2019/06/23/asean-members-to-strengthen-joint-capacity-andcapability-in-addressing-climate-change/ Manila, Accessed on Sunday, May 31, 2020, at 6.21 p.m

${ }_{33}$ Ho Juay Choy, Melissa Low, Et.al, 2016, Handbook for ASEAN Government Officials on Climate Change and SDGs, ASEF, Singapore, p. 55.

${ }^{34}$ Ibid. p. 55.
} 


\section{Borneo Law Review Vol.4 No.2 \\ Desember 2020}

limiting global warming to well below $2^{\circ} \mathrm{C}$ and pursuing efforts to limit it to $1.5^{\circ} \mathrm{C} .35$ It also aims to strengthen countries' ability to deal with the impacts of climate change and support them in their efforts. The principal ambivalent feature of the Paris Agreement relates to that fact that it contains a pledge of the parties to start moving towards a clear path of progressive decarbonisation of the economy, based on the aim 'to reach a global peaking of the GHG emissions as soon as possible', followed by 'rapid reductions thereafter', so as 'to achieve a balance between anthropogenic emissions by sources and removals by sinks', to be reached in the second half of the 21st century. ${ }^{36}$

At the 16th ASEAN Summit in 2010 the ASEAN Leaders' issued a 'Joint Response to Climate Change'. They repeatedly urged for a global solution to the climate challenge as well as pledged for the development of a climate change resilient ASEAN community (ASEAN, 2010). In line with the latter, an ASEAN Action Plan on Joint Response to Climate Change (AAP-JRCC) was developed by the AMS. Based on the Roadmap for an ASEAN Community 2009-2015, it seeks regional co-operation opportunities in terms of adaptation and mitigation options, climate research and global climate negotiations. The ASEAN Working Group on Climate Change (AWGCC) of the ASEAN Climate Change Initiative (ACCI) was designated for the implementation of the Action Plan and a lead country was appointed for the co-ordination of the implementation of each action program point (adaptation; mitigation; Common activities for finance and investment, technology transfer and capacity building; and Strengthen co-operation with other regional co-operations). ${ }^{37}$

ASEAN's commitment to climate change is still limited to appeals to ASEAN member states but has not yet reached the establishment of a system that is ready to be implemented, such as restrictions on carbon production in each member states, so that ASEAN can regulate carbon distribution in the region and can reduce the impact of climate change. Substantive progress will be more likely if countries first understand the underlying reasons behind the existing stalemate on future next steps. ${ }^{38}$

\section{Conclusion}

\footnotetext{
35 European Commission, https://ec.europa.eu/clima/policies/international/negotiations/paris en accessed on Monday, June 01, 2020, at 8.10 p.m.

${ }^{36}$ Massimiliano Montini, 2015, "The Paris Agreement on climate change: miracle or disaster?" Environmental liability Lawtext Publishing Ltd, p.163

${ }^{37}$ Ho Juay Choy, Op. Cit, p. 57

38 Farhana Yamin \& Joanna Depledge, 2004, The International Climate Change Regime A Guide to Rules, Institutions and Procedures, Cambridge University Press, New York, p. 568.
} 


\section{Borneo Law Review Vol.4 No.2 \\ Desember 2020}

ASEAN as an organization that houses countries in Southeast Asia has shown a commitment to the prevention of climate change that occurs in the world, but the commitment that has been formed by ASEAN member states is only limited to cooperation to take steps those are educational or subtle in nature. Furthermore, European Union make a giant leaps in terms of reducing greenhouse gases which has caused climate change by establishing regulations and systems to control greenhouse gases in the region, this can be seen from the implementation of EU Emission Trading System schemes for member states. The steps that European Union has taken in reducing greenhouse gases can be adopted or modeled as a long-term commitment that needs to be taken by ASEAN, nevertheless, the political interests, readiness and willingness of each member states have to deliberated because ASEAN still relies on industries that produce greenhouse gases in contrast to the EU which has switched to environmentally friendly industries.

\section{BIBLIOGRAPHY}

Abeyratne, Ruwantissa. 2014. Aviation and Climate Change In Search of a Global Market Based Measure. SpringerBriefs in Law. London.

Agha Putri, Dewi. ASEAN-U.S Cooperation on Renewable Energy: ASEAN's Response to Climate Change Phenomenon, Intermestic: Journal of International Studies, Vol 3, No. 1, 2018.

AMAF Meeting. 2018. ASEAN Multi-Sectoral Framework for Climate Change: Agriculture and Forestry towards Food and Nutrition Security and Achievement of SDGs (Proposed Integrated Framework for AFCC Component 4) Hanoi.

Australian Government, 2015, Comparing Countries' Emissions Targets a Practical Guide, Commonwealth of Australia (Climate Change Authority), Australia.

Burtraw; Dallas and Michael Themann. 2018. Pricing Carbon Effectively: Lessons from the European Emissions Trading System. Resources for the future, Berlin.

European Union. 2015. EU ETS Handbook. European Commission.

Grasso, Marco. 2010. Justice in Funding Adaptation under the International Climate Change Regime. Springer. New York.

Juay Choy, Ho, Melissa Low, Et.al. 2016. Handbook for ASEAN Government Officials on Climate Change and SDGs. ASEF, Singapore.

Laing, Tim and Misato Sato. 2013. Assessing the effectiveness of the EU Emissions Trading Scheme. Centre for Climate Change Economics and Policy, London. 


\section{Borneo Law Review Vol.4 No.2 \\ Desember 2020}

Marceau, Gabrielle. 2016. Legal Issues on Climate Change and International Trade Law, Springer Nature, Switzerland.

Mizan R. Khan, Mizan. 2014. Toward a Binding Climate Change Adaptation Regime. Routledge. New York.

Montini, Massimiliano. 2015. The Paris Agreement on climate change: miracle or disaster? Environmental liability Lawtext Publishing Ltd.

Peeters, Marjan. An EU Law Perspective on the Paris Agreement: Will the EU Consider Strengthening its Mitigation Effort, Koninklijke Brill NV Leiden, Climate Law 6 (2016) 182195.

Peeters, Marjan and Huizhen Chen. 2015. Enforcement of emissions trading - sanction regimes of greenhouse gas emissions trading in the EU and China. Research Handbook on Emission Trading.

Prentice, Joshua. The Revision of the European Union's Emissions Trading System Ahead of the Fourth Trading Period, 2021-2030. Koninklijke Brill NV Leiden, Climate Law 8 (2018) 338348.

Quirico, Ottavio. 2016. Climate Change and Human Rights an International and Comparative Law Perspective. Springer. New York.

Shi, Yukun; Sudharshan Reddy Paramati and Xiaohang Ren. 2019. The Growth of Carbon Markets in Asia: The Potential Challenges for Future Development. ADB Institute No. 987.

Syukriah, Ana. Peningkatan Eksistensi UMKM Melalui Comparative Advantage dalam Rangka Menghadapi MEA 2015 di Temanggung. Economics Development Analysis Journal, Vol.2 No.2 2013.

Yamin, Farhana \& Joanna Depledge, 2004, The International Climate Change Regime A Guide to Rules, Institutions and Procedures, Cambridge University Press, New York.

\section{Legislations}

United Nations Framework Convention on Climate Change

The EU ETS Directive 2003/87/EC of The European Parliament and of The Council, Regulations on penalties for non-compliance.

\section{Internet}




\section{Borneo Law Review Vol.4 No.2}

Desember 2020

ASEAN, (AEC), http://www.asean.org/communities/asean-economic-community Jakarta, accessed on Sunday, March 29, 2020, at 1.30 a.m.

ASEAN, ASEAN Economic Community (AEC), http://www.asean.org/storage/2012/05/56.December-2015-Fact-Sheet-on-ASEAN-Economic-Community-AEC.pdf Jakarta, downloaded on Sunday, March 29, 2020, at 3.30 p.m.

ASEAN Centre for Energy, Multiple game plan for ASEAN in tackling climate change, https://accept.aseanenergy.org/wp-content/uploads/2019/12/Energy-Insight MultioleGame.pdfJakarta, downloaded on Sunday, May 31, 2020, at 4.05 p.m

European Commission, Paris Agreement, https://ec.europa.eu/clima/policies/international/negotiations/paris en accessed on Monday, June 01, 2020, at 8.10 p.m.

Manila Bulletin, ASEAN members to strengthen joint capacity and capability in addressing climate change, https://news.mb.com.ph/2019/06/23/asean-members-to-strengthen-jointcapacity-and-capability-in-addressing-climate-change/ Manila, Accessed on Sunday, May 31, 2020, at 6.21 p.m 